\title{
Curriculum Policy and The Politics of What Should Be Learned in Schools
}

\author{
BEN LEVIN
}

Item: A plan to remove calculus from the Ontario Grade 12 mathematics curriculum draws protests from high-tech companies and university engineering departments despite support from university mathematics departments who understand that participation rates in advanced mathematics have been falling significantly and the proposed change would actually improve overall mathematics learning.

Item: The Ontario curriculum for Grades 1 to 8 contains more than 3700 specific and general expectations for teachers and students to cover. Assuming a 200-day school year, this is more than two curriculum goals every day for 8 years. Although these expectations are grouped under a much smaller number of key learning goals, teachers want the number of specific expectations reduced while other groups are lobbying to include new areas as essential objectives.

Item: The Ontario high school curriculum already has 270 possible courses even though students only have a maximum of 12 options during their 4 years of high school. However, there are constant requests for new courses, such as women's studies, Black history, environmental awareness, workplace safety, entrepreneurship, and a variety of others.

$\mathrm{T}$ he content of school curriculum has always been the subject of controversy and considerable public attention in countries we have studied. This chapter examines the political dynamics around the construction of official school curriculum - that is, curriculum developed by governments or other sanctioned authorities for standard use in schools across a state, province, or country. The first part of the chapter provides a context for the discussion by describing the scope and nature of political discussion and decision making in government. The chapter then uses a framework based on the work of Young, Levin, and Wallin (2007) to examine the factors and processes that affect curriculum decisions. Examples drawn from the author's experience and the literature are used to illustrate these dynamics. The chapter concludes with an extended example. 
In this chapter, curriculum is defined as an official statement of what students are expected to know and be able to do. The informal or unofficial curriculum, despite its importance, is not discussed in this chapter. Nor does the chapter discuss issues of how local jurisdictions use policy to inform classroom instruction (what is actually taught), how and what teachers teach, or what students learn as a result. These are very important issues that are discussed elsewhere in this handbook. Because many curriculum questions are as much about teaching practice as about curriculum documents, debates over appropriate teaching methods are an essential part of the politics of curriculum and so are also part of the discussion in this chapter.

\section{Understanding Public Policy ANd Politics}

This chapter is primarily about politics, but politics in relation to public policy. There are many, many definitions of both terms-public policy and politics. Public policy is about the rules and procedures governing public sector activitywhat they are and how they are made. It can be thought of as either a subset of the study of government or an element in the study of various policy fields-health, education, justice, social welfare, transportation, and so on. Policy studies tend to focus on the processes through which policies are created and the effects of such policies once in place.

Policies govern just about every aspect of education-what schooling is provided, how, to whom, in what form, by whom, with what resources, and so on. The application of these terms to curriculum is evident. Curriculum concerns what is taught-a fundamental aspect of schooling and thus of public policy.

Policy studies sometimes give short shrift to questions of politics, treating policy creation and evaluation as an intellectual activity based primarily if not solely on the actual content of the policies. In reality, though, policy is inextricably connected to politics and the attempt to separate them is unhelpful to understanding or action.

The role of politics in policy is troubling and misunderstood by many educators, who feel that education is a matter of expertise and should be beyond politics. The apolitical or even antipolitical view of many educators is not helpful because it takes attention away from the reality that politics is the primary process through which public policy decisions are made. Even the choice to use a supposedly nonpolitical mechanism such as markets is a political choice (Plank \& Boyd, 1994).

Some definitions of politics focus on formal processes of government, such as elections, political parties, and division of powers. Other definitions, closer to my understanding, are broader, seeing politics as extending beyond formal processes to include a wide range of informal influences and larger social processes. Political processes operate even in the most authoritarian societies, though their forms differ depending on political culture and institutions. One of the most enduring definitions of politics is Lasswell's (1958), "Who gets what?" This definition can be applied to every setting, from a country to a school or classroom.

Politics is about power. Since not all can have what they want, the question is who does get what they want and who does not. Tinder (1991) describes a political system as "a set of arrangements by which some people dominate others" (p. 162). In every setting, from classroom to country, political influence is usually highly unequal, and those who have the least status tend also to have the least influence on political decision making.

Every education policy decision can be seen as being, in some sense, a political decision. However, this does not mean that every educational issue will be the subject of intense public discussion and political lobbying. Indeed, most policy decisions in education, including curriculum decisions, are made with little or no public attention. Sometimes these decisions are controversial and highly political within the organization itself. A subfield of education politics, micropolitics, developed to examine some of these small scale political interactions (e.g., Ball, 1987; Hoyle, 1982). But whether controversial or not, education policy decisions, because they involve questions of public choice and concern, are essentially political in nature (Manzer, 1994).

A substantial body of research and scholarship in education addresses issues of policy formation and implementation from a variety of conceptual positions. Examples of these different perspectives can be found in handbooks or collections such as Hargreaves, Lieberman, 
Fullan, and Hopkins (1998) and Bascia, Cumming, Datnow, Leithwood, and Livingstone (2005). The education policy literature could be strengthened if it were better linked to the larger literature on public policy and politics, although the latter has more sophisticated frameworks and modes of analysis (for an overview of this work see Howlett \& Ramesh, 2003; for a particularly insightful discussion see Dror, 1986).

Most frameworks for understanding politics and policy formation address similar topics. Central features of any analysis include the institutional setting and structure around decisions (e.g., Crowson, Boyd, \& Mawhinney, 1996), how issues come to be on the political agenda (e.g., Kingdon, 1994), and the processes through which decisions are made in the face of different points of view (e.g., Ball, 1990). Attention may also be given to the process of implementationwhat happens to policies after their official adoption. Implementation became a more intensive focus of attention starting in the late 1960 s as analysts began to realize that policies did not always produce the intended results (e.g., McLaughlin, 1987; Wildavsky, 1979). In one comparative study of education reform politics, Levin (2001) used a typology of origins (where policy comes from), adoption (from an idea to a decision), implementation, and outcomes (results, intended or not, of decisions). However any such categorical system is only a device, since in practice political processes are highly interactive. The discussion in this paper uses a heuristic framework drawn from Young et al. (2007), who propose analyzing political decisions in terms of five overlapping categories: issues, actors, processes, influences, and results.

\section{How Government Works: An Inside Perspective}

Curriculum politics should be understood as part of the overall process of government and especially the influence of politics. The dynamics of government are not well understood by most people outside of government-for that matter, also by many people who work in government-and many of the scholarly discussions of policy and politics do not reflect the realities of government to any substantial degree. The first part of this chapter describes some of these features as a prelude to a discussion of curriculum politics and policy.
I have spent half my career as a senior official in government, working closely with politicians and political staff as well as civil servants to develop and implement education policy agendas. My research and academic work - the other half of my career-have also given me the opportunity to work closely with political leaders and senior officials and to observe political decision making in several other countries.

Contrary to conventional wisdom, politics in my experience is an intensely rational activity. However, the premises behind political rationality are different. Politicians are no more selfserving or indifferent to evidence than are educators or civil servants. Understanding the politics of curriculum requires an understanding of the factors that affect elected governments and especially the powerful constraints that limit both understanding of what to do and capacity to act.

These dynamics are illustrated through the following six general assertions; their implications for curriculum politics are developed later. In my view these dynamics apply to all elected governments, even though political structures, cultures, and practices can differ substantially across jurisdictions. For example, the United States system of checks and balances has different features than do parliamentary systems such as the United Kingdom, Australia, or Canada. Politics may look different in decentralized or federal states than in unitary states. But whatever the form, elected governments are subject to pressures and constraints based on voter preferences, election timing, and the views of key interest groups. In other settings, where elections do not exist or are not particularly meaningful, political dynamics might look quite different. However, as illustrated by the overthrow of totalitarian regimes in various countries in the last couple of decades, every government has to pay some attention to the views of elites of various kinds, even if not to citizens more generally.

\section{Voter Interests Drive Everything}

Everything in government occurs in the shadow of elections. Although stakeholder views do matter, as will be discussed later, government understanding of the views of voters in general matter much more. Every government is thinking all the time about how to improve its prospects for being reelected, which means trying to do what voters want. Some people find this 
cynical, but it is hard to see what else politicians could do. After all, concern for reelection is largely about doing what most people want, and presumably people elect governments for precisely that purpose. A government that does not satisfy enough people will be tossed out of office. It seems unlikely that voters would like governments better if the latter had the so-called courage to do what is unpopular. From the viewpoint of those elected, doing the unpopular is precisely how a government gets defeated in the next election. The British cabinet minister in the wonderful British TV series Yes Minister always reacted with dismay when his chief civil servant, Sir Humphrey, called for taking a courageous stand, since this inevitably meant doing something that would get him into serious trouble.

Voters exercise a double standard around government. When individuals want a government to do something that may not be very popular, people talk about governments needing to have political will. However when a government does something people do not like, whether popular or not, it tends to get labelled as ideology rather than political will.

Governments do attempt to shape as well as respond to public opinion. Sometimes they want to give the perception of action even when they are not doing much, and sometimes they want to give the perception that changes are less significant than they really are so as to reduce opposition. Rhetoric is a vital part of politics (Edelman, 1988; Levin \& Young, 2000), and government statements of intention or announcements of action cannot always be taken at face value. They have to be read through the lens of political communication.

It is also important to remember that voters are not necessarily very interested in every public issue; and even if voters are interested, they may not be knowledgeable. There are too many public issues for even the most committed citizens to know about beyond the most superficial level. People have lives to carry on, and public affairs are inevitably only one part-and for many, not a very large part—of those lives. This means that citizen knowledge of and attention to issues can be very limited. Hence, there is pressure on politicians to communicate in very simple messages. As one political leader told me, "If I can't explain it in 25 words or less, people stop listening." At the same time, voters can care deeply and feel strongly about issues about which they know very little. For example, people may have strong views about something like global warming without having any significant knowledge. Education policy is particularly susceptible to this situation as pretty well everyone has some experience of schooling and therefore opinions about how it ought to work. Research in social psychology (Kiesler \& Sproull, 1982) has shown that people are very susceptible to generalizing on the basis of a few rather unusual cases.

Still, it would be a mistake to believe that governments are about only image and impression. They are usually genuinely concerned about the results of their actions and policies. They do believe that their policy goals will make society better. They do want to fulfill their commitments to voters, and programs and policies are the means of doing so. They do not set out to make a mess of things any more than schools set out to have high numbers of dropouts or unhappy parents. Moreover, a mistaken policy can create very large political costs. Voters do tend to toss out of office governments whose performance is disappointing - as virtually all eventually are.

\section{Governments Have Limited \\ Control Over the Policy Agenda}

Although every government comes to office with a set of policy ideals or commitments, the reality is that much of what governments attend to is not of their own design or preference. Governments have to be in whatever businesses (the plural is deliberate here) people see as important.

Governments try to do everything all at once because that is what citizens and voters require of them. The presence of diverse and conflicting goals means that governments are pulled, often strongly, in different directions at the same time. Policies may be contradictory or incoherent as governments try to maintain political credibility and social harmony by softening the edges of what they do or by giving a little bit to many different and even competing agendas. In these circumstances, clarity of purpose is not necessarily a virtue in that it can exacerbate divisions that cannot easily be reconciled.

Government agendas are certainly shaped in part by political commitments, party platforms, and the views of key political leaders. Governments do try to keep a focus on meeting the 
commitments they made when elected. However, they are also influenced, often to a much greater extent, by external political pressures, changing circumstances, unexpected events, and crises.

As soon as a government is elected, various groups try to influence its agenda in accord with their own. This is in many ways the essence of the political process. It means that politicians are constantly bombarded with requests or demands to do things, stop doing things, increase funding, decrease funding, pass legislation, repeal other legislation, and so on. As populations have become better educated and better organized, the number and intensity of the pressures on politicians has risen.

Nor are people necessarily reasonable or consistent in their demands; as Arrow (1970) pointed out long ago, public preferences do not necessarily line up in rank order. The same people who demand more services from governments may also demand lower taxes. Those who in one year argued vehemently in favor of reduced government spending might the following year be just as impassioned when pointing out the negative consequences of the reductions. In regard to education, people can be in favor of more testing and more creativity or of tougher standards and more individualization at the same time. People can and do hold inconsistent beliefs, but political leaders must do their best to accommodate these inconsistencies in some way.

Unanticipated developments can also affect political agendas. When the unexpected happens, whether an economic downturn, a natural disaster, or some other new development, governments must respond in some way, even if that means taking attention and resources away from other activities that were high on the priority list. As Dror (1986) puts it, there is "at any given moment a high probability of low probability events occurring. In other words, surprise dominates" (p. 186). Examples of such surprises abound, from $9 / 11$ to SARS, from a sudden rise (or fall) in oil prices to the unexpected death of a key political leader or a street revolution. Many events can render carefully developed plans null and void in an instant.

While some of the pressures on government relate to very important, long-term issues, short-term details can also be very important. One cannot assume that the former will always be more important than the latter. Very small items can turn into huge political events. In the private sector, $95 \%$ customer satisfaction is outstanding; in the public sector, $5 \%$ of clients complaining can lead to a political disaster. For example, a single instance of a problem-say a child in public care being abused or injured or a patient dying in a hospital waiting room-can undermine an entire system that may actually be working reasonably well and divert attention and resources from activities that are really much more important.

Governments are particularly susceptible to issues that take on public salience through the media (Levin, 2004a). Most people get their information about public events from the mass media; an issue that is played up in the media often becomes something that a government must respond to, even if the issue was no part of the government's policy or plan and even if the media report is inaccurate or misleading. Media coverage is itself motivated by a number of considerations, but long-term importance to public welfare is not necessarily one of them (Edelman, 1988, 2001; Neuman, Just, \& Crigler, 1992). Indeed, novelty is an important requisite for the media in order to sustain reader or viewer interest, so governments are likely to be faced with an ever-changing array of issues all of which supposedly require immediate attention.

The significance of the media is also illustrated by the consistent finding that where people have first hand knowledge - such as of their own schools, hospitals, or child care centerstheir satisfaction level is higher than for the system in general, where their prime source of information may come through often negative media coverage.

\section{There Is Never Enough Time}

Governments are in some sense responsible for everything. Government leaders have to make decisions about a vast array of issues-from highways to the environment, from financial policy to education, from health to justice systems. And, as just noted, they are likely to face an unending set of other pressures on their energy and attention. In parliamentary systems, cabinet members not only have responsibility for their own area of jurisdiction-which can be enormously complicated and fraught with difficulties-but are also supposed to participate in collective decision making on a wide variety of other matters facing the government. Each issue 
has to be considered not only in terms of its substance, but also from the standpoint of public attitudes and political implications. The nature of political life is such that there is no respite from these demands. A politician may leave her or his office, but almost every social encounter will also lead to new pressures or requests. Politicians have little opportunity for a private life.

There is, consequently, never enough time to think about issues in sufficient depth. The political world is a relentless parade of events, issues, and required decisions - few, if any of which, can be put off for sober reflection. Some sense of this pace is captured in the TV program The West Wing, except that the real situation is generally more messy even than this portrayal, with more simultaneous demands and pressures being handled. Senior government leaders, both politicians and civil servants, work under tremendous time pressures in which they are expected to make knowledgeable decisions about all the issues facing them within very short timelines and without major errors. This is impossible, but it is nonetheless what citizens expect from their leaders.

The result is that important decisions are often made very quickly with quite limited information and discussion. This is not because politicians necessarily like making hurried or uninformed decisions, but because there is no alternative to doing so. There is an unconfirmed story from a large country that illustrates this dynamic. The Minister of Education went to see the Prime Minister with two major policy proposals. The Prime Minister told the Minister of Education that he could have one only and could pick which one. That is how the country ended up with a very powerful policy change.

The pressure of multiple issues is also one of the reasons that policy implementation tends to get short shifted. As soon as one decision has been made there is enormous pressure to get on to the next issue. Even with the best intentions, it is hard to get back to something from months ago to see how it is progressing since meanwhile so many other issues have arrived on the doorstep demanding immediate attention.

During my time in government, I have often been amazed not by how many things went wrong, but by how many decisions turned out reasonably well, considering the circumstancesmultiple contradictory pressures, insufficient time, inadequate knowledge- under which they were made.

\section{People and Systems Both Matter}

Much of what a government does is shaped by the individuals who happen to occupy critical positions, regardless of their political stripe. Any political party is likely to contain a wide range of views and positions; in statistical terms, the within-group variance in ideas in a party is likely to be much larger than the variance between one party and another. So the individuals who come to hold certain positions are important. Presidents in republican systems are of course powerful examples; who the president is matters as much or more as his or her party affiliation. The same applies in parliamentary systems. Some ministers carry quite a bit of weight in Cabinet and can get their way on important issues, while others have difficulty getting their colleagues to support any major policy thrust. Some politicians are quite pragmatic and willing to reshape policy in light of changing pressures or public preferences, while others are deeply committed to particular values and work hard to promote and implement a course of action over years even in the face of substantial opposition. Some Cabinet ministers or key political operatives understand and use research, while others may be ignorant or even dismissive. Some politicians are superb public communicators, while others are not.

The nature of government systems also matters. The roles of various departments and central agencies, the relative power of individual ministers vis-à-vis central government, the way in which issues come to decision-making bodies such as a Cabinet, and the kind of information that accompanies them are all important in shaping the way policies are constructed and delivered. Some governments stripped away much of their internal analytic capacity in the 1980s and 1990s as part of the effort to reduce spending, limiting their ability to design and implement effective policy. Similarly, more checks and balances in a system tend to make decisive action much more difficult-for better or worse. New Zealand in the late 1980s implemented very dramatic changes in overall public policy very rapidly because it had few such restraints (Boston, Martin, Pallot, \& Walsh, 1996); a similar degree and rapidity of change in federal states 
with divided powers such as in the United States, Canada, or Australia is hard to imagine.

\section{A Full-Time Opposition Changes Everything}

Imagine how different any workplace or job would be if there were people whose full-time job it was to oppose publicly everything being done. Imagine also that they could use less than scrupulous means of doing so and that there was a tendency for people to believe their criticisms ahead of any other explanations. Might that not change the way people went about their work?

Yet that is precisely the situation facing every elected government. Oppositions are there to oppose. They will work hard to show how government actions are wrong, venal, or destructive. In doing so, they will not generally be particularly concerned with balance or fairness in their accounts. Governments have to think at all times about the worse possible construction that could be put on any action since just such a view will inevitably be put forward by the opposition.

While many people decry negativity in politics, politicians use this strategy not necessarily because they like it, but because they think it works. If voters believe negative portrayals and vote accordingly, then political parties will use them. If conflict is what attracts public attention, then conflict is what politicians will create since public attention is what they must have. A politician friend once told me that he got far more publicity and recognition from a certain public relations gesture that he knew was rather narrow than from any number of thoughtfully articulated policy papers, so the public relations gesture would continue. The problem is that over time an emphasis on the negative can certainly increase voter cynicism about politics and thus worsen our politics. Imagine what would happen to any other industry - say the auto industry-if the major players ran endless ads attacking each other on the basis of poor quality, shoddy business practices, or safety violations. Public confidence in the industry would be badly undermined. Yet that is in large part how political communications work today in some countries.

\section{Beliefs Are More Important Than Facts}

Researchers are often convinced that policy ought to be driven by research findings and other empirical evidence. Educators may believe that education policy should be based on their knowledge and experience. From a political perspective, however, evidence and experience are not enough to drive decisions, and they may be among the less important factors. I have had politicians tell me on various occasions that while the evidence I was presenting for a particular policy might be correct, the policy was not what people believed, wanted, or would accept.

For politicians, what people believe to be true is much more important than what may actually be true. Beliefs drive political action and voting intentions much more than do facts. Witness the strength and depth of public support for various measures that clearly fly in the face of strong evidence. Many people continue to believe, in spite of compelling evidence, that capital punishment is a deterrent for crime or that welfare cheating is a big problem. Others are convinced that amalgamating units of government saves money, that free tuition would substantially increase accessibility to postsecondary education for the poor, or that retaining students in grades will improve achievement even though in all of these cases a strong body of evidence indicates otherwise. Where beliefs are very strongly held, political leaders challenge them at their peril. As Marcel Proust (1913/2004) put it,

The facts of life do not penetrate to the sphere in which our beliefs are cherished ... they can aim at them continual blows of contradiction and disproof without weakening them; and an avalanche of miseries and maladies coming, one after another, without interruption into the bosom of a family, will not make it lose faith in either the clemency of its God or the capacity of its physician. (p. 212)

\section{A FRAMEWORK FOR Understanding Curriculum Issues}

From this discussion of government and politics generally, the discussion now shifts to focus on curriculum decisions and politics. The discussion is organized in terms of the framework described earlier-issues, actors, processes, influences, and results-recognizing that these, like any other categorical framework, are intellectual 
organizers only and that actual events do not fall into neat categories.

\section{Issues: Scope of the Politics of Curriculum}

\section{Elements of Curriculum}

Most curricula are organized around at least two levels of objectives-very general or broad goals and then much more specific learning activities and objectives. Curriculum documents and policies may also endorse or support, explicitly or not, particular teaching and learning practices. These relationships have themselves been changing over time as a result of growing knowledge-for example, increasing awareness of the importance of teachers' assessment practices (Black \& William, 1998).

Curriculum politics and policy choices are also increasingly related to larger issues of school change and improvement and to varying theories of what it is that shapes the outcomes of education. At one time there may have been a common sense assumption that curriculum was central to the enterprise, in that what was taught is what would be learned. Decades of experience with educational change have made it evident that the situation is much more complex. There is a substantial debate as to how important formal education as a whole is in shaping student outcomes, with some arguing that socioeconomic status and other nonschool factors are by far the most important influences on outcomes while others believe that what happens in schools can play an important role (Levin, 2004b).

As governments have attempted to support large-scale educational change (Fullan, 2000), curriculum has become less an activity in its own right and more one element in a more comprehensive approach to education change. In many jurisdictions with centralized curriculum, review and renewal processes have been altered to be more consistent with wider education programs. In other settings curriculum has been a prime vehicle for realizing wider change (e.g., Luke, 2004). The United States is a particularly interesting case in that there is a national education reform strategy-No Child Left Behind (NCLB) - that is based largely on demanding curriculum standards, yet curriculum is controlled mainly at the district or even school level, creating some substantial disjointedness. The implicit theory of action in NCLB is that accountability requirements can be the primary drivers of improved educational practices and of improved results, a belief that is extraordinarily contentious and has prompted an enormous political debate in the United States.

The politics of curriculum can be thought of as involving two kinds of discussions. The first concerns the overall shape of school curricula: what subjects will be included (or excluded), how much of each, and at what stage of students' education. Examples would include debates over whether literacy or mathematics are getting a sufficient share of the school day and school year, whether sex education or religion should be part of the curriculum, when students should first study a foreign language, or the degree to which they should be required to study music or physical education.

The second kind of debate is over the content of particular subjects. People will disagree over what should be included in each subject and what should be included at various age levels for students. Should spelling be taught explicitly? If so, when? How much of their own country's history and geography should students learn as opposed to that of other countries? Should all students learn algebra? Should all students—or any — be required to study Shakespeare? These debates take place not only in the most obvious areas, such as what is taught in history or studied in literature and at what age, but also in areas that might be thought to be more objective, such as science or mathematics. For example, should global warming be a part of science curriculum?

In addition to the content of specific subjects, schools are seen as the place where children will be inoculated against all social ills or taught all the virtues from street proofing to AIDS, antismoking, drinking, and drug abuse education. Schools are expected to prevent bullying, obesity, and anorexia while also eliminating racism and promoting equity in all its forms. In many cases these topics cut across the formal school curriculum, so who provides what instruction and when can be an important curriculum issue.

Some of these discussions are a matter of pragmatics. There simply are not enough hours and days in 12 years of schooling to accommodate all the areas people want children to develop. A Canadian public opinion poll a few years ago found that people wanted more of every subject in the school curriculum, but did not want a longer school day or year (COMPAS, 
2001). So debates take place about the relative importance of science or economics or the arts or physical activity in the competition for scarce school time. These discussions can be intense in part because they are often led by people with a strong personal interest in the decision.

A second set of arguments, often much more vitriolic, occur when curriculum debates occur due to disagreements on important value questions. Because schooling is seen as so fundamental to the development of our children, it can turn into a battleground for wider social disputes. Thus people will disagree about whether particular content should be part of school curriculum at all. Sex education is one obvious example, but significant philosophical or value disagreements are also expressed in many other areas. There can be deep-seated arguments about the content of history and literature curricula, such as how much attention in these subjects should be given to minority groups or to dissidence. People's fundamental ideas about their country get expressed in disputes over the role of first languages for immigrant students or around curriculum about various forms of diversity and human rights. Any issue that is politically contentious can also turn into a curriculum dispute. Recent debates in the United States and elsewhere about evolution provide another example in which differences in religious beliefs get expressed in curriculum policy disputes. Even in fields such as literacy and numeracy there are in some places bitter disputes, such as the reading wars and math wars. These debates are sharper because they embody deeply held views not only about the nature of education but about essential life values.

As mentioned, an important element of the politics around education is that everyone has gone to school, so just about everyone has a feeling of being knowledgeable and a personal response to educational issues. The same would not be true of health care or environmental policy or energy policy. People's own school experience, whether primarily positive or negative, deeply affects their views about education policy. One important result of the universal experience of schooling is that adults, like children, tend to see curriculum as a collection of subjects and topics without necessarily requiring coherence or integration across the curriculum.

Another significant feature of curriculum politics is that in many cases questions of content cannot be separated from teaching practice.
Many of the most heated issues in curriculumfor example, whole language or constructivist mathematics-are as much about teaching methods as they are about curriculum content. On the other hand, there are occasions when the whole concern is about the content of curriculum documents with little attention to pedagogy. For example, debates about whether particular topics should be included in history curriculum or certain books in literature courses may be entirely about what appears in the official document; what teachers do if and when they teach the content may be of little concern in the political arena.

These comments on the scope of curriculum politics reinforce the claims earlier in the chapter about the multiple influences on political debate and decisions. Some of the issues around curriculum are largely symbolic, while others may be deeply connected to the fundamental purposes and activities of schooling. Politicians and governments must try to deal with all these competing demands in a way that appears to reflect at least a modicum of coherence and concern for the longer-term welfare of education.

\section{Actors-Who Is Involved?}

Curriculum politics involve a wide range of participants. An important first question is where the authority over curriculum rests. Education governance typically involves some combination of national, local, and school participation; and in federal systems, education governance will have a fourth (and often primary) level at the state or province. The division of powers and responsibilities across these levels is quite variable from one country to another. In most jurisdictions, final authority over curriculum rests with national or subnational governments. In many federal systems it is provinces or states that control curriculum. In a few situations curriculum authority is largely located within individual schools.

The central role of governments inevitably brings into play a range of both political and bureaucratic elements. Although a cabinet usually has a single person charged with responsibility for education, many other political leaders may also have views; and if curriculum decisions go through a political vetting process, they may be subject to all sorts of political influences including preferences of individuals. An individual in a key position can either shape or hold up decisions if 
determined enough. For example, a powerful cabinet member or political advisor may be able to insist that a particular element be added to or dropped from a proposed curriculum.

A second important element of governance structure is the institutional role of elected lay persons as against civil servants or experts. Countries vary significantly in how much authority lay people have in shaping education policyvehicles range from elected ministers to local school authorities to school councils or governing bodies involving parents and others. Each of these forms will bring different dynamics to curriculum politics. Depending on national governance arrangements, schools or districts have varying degrees of control-from almost none to quite substantial-over the formal curriculum.

Whatever the formal control system is, in almost all settings, schools have some influence if only through the choice they are able to make as to which courses and programs are actually provided and the amount of attention that is given in the day to day life of the schools to particular subjects or topics. High schools, for example, have to choose which optional courses to offer. Elementary teachers and schools typically make important decisions about curriculum emphasis, especially where-as is often the case-the formal curriculum has more elements to it than can be taken up in most classrooms. Schools or districts also often decide on the areas of the curriculum that will be the subject of professional development.

The main education stakeholder groupsteachers, principals, senior administrators, and elected local authorities where they exist-are almost always involved in curriculum reviews and decisions. Subject matter experts from schools and universities typically play a central role in the curriculum formation and review process and may also be very involved in public debates. Indeed, a central dilemma in curriculum formation is the balance between subject matter expertise and larger perspectives on the role of a given topic in the overall school program. Not surprisingly, those associated with each subject or topic will advance its importance-which, it must be pointed out, is often linked with their own employment prospects and importance. Of course scientists or music teachers or tradespersons also genuinely believe that their field is important for students, but one cannot ignore the role of self-interest in these debates.
Postsecondary institutions often have a powerful influence on school curriculum, especially in secondary schools, through the setting of entrance requirements to their institutions. Since secondary schools often see themselves-and are widely seen by students and parents-as preparing students for further study, the schools may find themselves quite constrained by requirements set by tertiary institutions. On the other hand, views about school curriculum expressed by the tertiary sector may not be particularly well grounded in evidence but may rest on the beliefs of individuals holding key roles. It is particularly the case that experts tend to believe that all students need more of their subject and at a higher level.

Since, as noted earlier, schools are widely seen as playing a central role in the socialization of children and young people, a wide range of interest groups may be involved in curriculum politics depending on the issue. For example, business groups often have strong views about various aspects of secondary curriculum-as illustrated in the example later of calculus in Ontario. Various industries will try to promote subjects and programs that support their labor market needs. Within government, other departments may put pressure on the education ministry for their favorite causes - such as innovation units promoting the use of technology or culture ministries promoting the arts.

In the wider society, many groups want the curriculum to reflect particular issues and perspectives-for example, the desire to include the language, history, and literature of various minorities and indigenous peoples or the ongoing debate about the role of the arts, or views on the place of foreign languages, or education for entrepreneurship, or the pressure to embody religious views in school curricula. As will be discussed in the next section, curriculum processes do not necessarily provide very much direct opportunity for input from various interests. As usual in political processes, those bodies that are better organized and financed or whose concerns are more deeply felt will tend to be much more active and may have disproportionate influence.

Curriculum can also be influenced significantly by other policies. Student assessment policies in education may shape curriculum decisions, especially where assessment policies are not linked to curriculum. In all settings assessment practices can be important drivers of 
what is actually taught. Where assessment is carefully linked to curriculum, this may not be a problem. However where assessment is disconnected from curriculum, the implications may be problematic. The requirement for high standards measured by tests and school ratings in NCLB in the United States are affecting teaching practices. That effect will only be positive if schools and teachers understand the standards and if the tests are carefully aligned to appropriate curricula and teaching methods-conditions that are very hard to achieve in a highly decentralized education system.

\section{Processes-How Are Curriculum Policy Decisions Made?}

Curriculum decision processes depend on governance systems discussed earlier. Jurisdictions normally have well-developed formal processes for creating and revising curricula. Typically these processes involve bringing together groups of experts and sector representatives to draft the elements of a new or revised curriculum. Teachers of the subject will often be in the majority, with representation from postsecondary subject experts as well. The processes are often organized and to some degree directed by government officials from ministries of education. Typically a curriculum review or renewal process would include examining the existing curriculum, gathering data as to the strengths and weaknesses of current arrangements, considering various ideas for changes, and trying to arrive at consensus on recommendations for the new curriculum. Sometimes a new curriculum will be created and released to the system, while in other cases it may be released initially on a pilot basis and then revised to a final version. Altogether curriculum processes can be quite extensive, sometimes taking several years from start to completion. However, if substantial authority is vested at the level of the local school, curriculum development or renewal is likely to be much more informal and ad hoc, as no school will have the resources or capacity to undertake these larger processes.

Expertise in a subject area-and even expertise in teaching the subject-does not necessarily equate to expertise in constructing a curriculum. By definition experts know more and care more about their subject than will most teachers. The danger in an expert-dominated curriculum development process is that the product will be something that can be used effectively only by people with high levels of expertise, but the reality of almost all schools everywhere is that most teachers of a subject, especially in elementary schools, will have only a limited background in that subject. One danger in curriculum development then is the production of curricula that are not readily usable by ordinary teachers. A colleague once described a high school mathematics curriculum as, "It was developed by the six best teachers in [the province] and they are about the only ones who could teach it successfully." Interest groups can and do promote ever-higher standards for their subject and then use those standards to argue for more time in the school schedule as well as for more teachers, higher qualifications, and more resources.

This example illustrates the importance of views about the relationship between the formal curriculum and real teaching and learning practices in schools. The gap between the two has been well known at least since the time of John Dewey. Many curriculum experts agree that formal curricula may have only a vague relationship to actual teaching and learning practices (e.g., Cohen \& Spillane, 1992). Various efforts have been made in the last few decades to produce curriculum in ways that would have a greater impact on students' real experiences. These efforts range from so-called teacher-proof curricula, in which teaching practice is built into the curriculum at a high level of specificity, to attempts to connect new curricula with professional development so as to change teachers' practices. However given the nature of schooling and teaching, with very large numbers of teachers of quite varied backgrounds in highly varied contexts and with considerable autonomy in their daily practice, central attempts to circumvent these limitations are unlikely to be successful. More is said later on the issue of implementation of curriculum.

The expert-dominated approach to curriculum development is changing as experts no longer have quite the same political legitimacy they once did. An increasingly better educated and more vociferous public is demanding greater input in all areas of public policy. Governments are therefore moving away in many areas of policy development from reliance on experts in favor of greater involvement of average citizens. Governments (and indeed nongovernmental organizations) are much more inclined today to 
use various forms of open consultation and opinion gathering as part of policy formation. In curriculum policy this trend can be seen in the increasing degree of nonexpert participation. Curriculum review parties are now more likely to include parents or students or non-educators such as business representatives. As discussed in the next section, these changes in composition can have significant implications for the ways in which curriculum processes unfold because they will bring different and more diverse interests to the table.

Curriculum review groups do not do their work in a vacuum. Sometimes these processes proceed relatively smoothly, but they can also be highly contentious. Where important disagreements exist about curriculum there may be intense lobbying by various interests as to who should be named to a working group. Although these processes are not often documented, some interesting accounts do exist of the politics of curriculum review. For example, Evans and Penney (1995) provide an analysis of discussion in England about the physical education curriculum, outlining the debates that occurred within a curriculum committee. More such accounts would be valuable in understanding these processes more fully.

A further consequence of expert input is the clash between experts with competing viewsfor example, those who favor new pedagogic approaches versus advocates of traditional content organization and teaching. Mathematics is a good example, pitting advocates of the National Council of Teachers of Mathematics (NCTM) standards or their equivalent against advocates for traditional approaches to mathematics. The clash of expertise is often a subject of media interest as well, with each side in a dispute seeking to marshal experts to support its position.

Curriculum formation may also be linked to much more public political processes. Public debates around curriculum issues can occur simultaneously with official processes-as, for example, when public interest groups are aware of and try to influence the outcomes of the official process by lobbying for particular changes. Or public debate and concern can lead to an official process as the system tries to respond to public concerns, as is evident in debates about issues such as global warming or the place of indigenous peoples. Or debate can erupt following a formal proposal as various interests mobilize to change a recommendation they do not support, as in the case at the end of this chapter.

\section{Influences—What Shapes Decisions?}

The earlier part of this chapter outlined the range of factors that influence government decisions in general, from ideology to lobbying to personal beliefs to media attention. The same influences will apply to curriculum decisions. One essential tension in curriculum decisions, as already noted, is between expert opinion and concerns of key interests or of the general public. Political leadership will take account of expert opinion, but will inevitably take much more interest in public opinion and particularly the views of opinion leaders in key sectors or constituencies.

Even where the curriculum process is dominated by experts there may be substantial disagreement on what to do. Teachers may see curriculum issues quite differently from postsecondary disciplinary experts. The latter may focus on the need for high level skills in their own area, whereas teachers may be more concerned with a curriculum that will work for students with widely varying skills and interests. Advocates may want more topics at higher levels, whereas classroom teachers may push for exactly the opposite. In some fields, teachers of the subject are themselves deeply divided on key curriculum and teaching questions-for example, in their views about integrated versus subject specific curricula or in their views on the importance of learning names and dates in history. Teachers also have varying opinions on issues such as the relevance of fields, such as gender studies as opposed to more traditional disciplinary boundaries, or on the value of project work.

A stark example of the level of disagreement that can arise over curriculum issues is the debate in the United States over the best ways to teach reading. The National Reading Panel report in 2000 made a set of recommendations around literacy instruction that immediately became highly contentious. In a vigorous and often acrimonious public debate (e.g., Allington, 2002; Coles, 2003; Schoenfeld, 2006), various participants not only proposed quite different approaches, but also in many cases attacked each 
other's understanding of the evidence and sometimes raised issues of personal integrity.

\section{The Role of Research}

Research has increasing importance in influencing education policy as a more educated population is more inclined to want evidence about public policy issues. This growing interest is evident in many areas of public policy, such as health or environment or energy, where claims grounded in research form an important part of public debate. My strong impression is that education policy debates make more use of empirical evidence than ever before. The growth of various research networks in and across countries as well as the creation of new vehicles for sharing and disseminating research are indicators of this shift (Levin, in press). In school practice too there is growing interest in the use of evidence to guide decisions about teaching and learning practices (e.g., Bernhardt, 2003; Marzano, 2003).

The interest in research does not, however, mean that there will now be a direct link between research results and policy choices; the latter will always remain the result of political processes, and research will play a role in and through broader social and political processes (Levin, 2002, 2005). The commitment to evidence is shown in that all sides in the political debate, even those whose theoretical stance is to see evidence as being largely the handmaiden of political ideology, do attempt to bring evidence to bear whenever possible and do use it to legitimate and support their own theoretical positions. Clearly research is used to bolster predetermined positions, but any careful thought will show that empirical evidence can also shape and change public and professional views on important questions. One needs only to think of examples such as retention in grade, tracking in secondary schools, or the impact of socioeconomic status on school outcomes to see how our ideas about schooling have been influenced by research. To say that these ideas have not transformed practice does not negate their significance any more than the fact that many people still smoke should be taken to mean that the research on the effects of smoking has had no impact.

There are important barriers to the use of research in curriculum policy. Most importantly, in many areas of curriculum-probably in most areas-there is not enough knowledge to guide policy or practice sufficiently; and quite often, existing knowledge is not available in a form that speaks effectively to the real problems and issues of policy and practice. However, even where there is a substantial body of knowledge, research evidence will not trump political pressures. Instead, it may play an important role in creating or legitimating such pressures.

The role of research is especially difficult where the research evidence is equivocal or is presented by partisans as being equivocal. When contradictory research findings are the subject of public debate, as has been the case in areas such as reading and mathematics teaching, citizens are likely to be confused and to revert to their fundamental beliefs whether supported by evidence or not. Given the growing significance of research, advocates for various positions are increasingly likely to try to draw on research to support their positions.

An interesting question is the degree to which curriculum review is actually informed by data and evidence. Curriculum review will generally take account of emerging knowledge in the field under discussion precisely because the process has so much expert participation. More recently, in keeping with a general trend in education toward using student assessment data, curriculum review may include data on student outcomes, both for the curriculum overall and for particular groups of schools or students. However, regular use of student outcome data to guide education policy is still not standard practice everywhere. Nor do curriculum working groups necessarily pay careful attention to research as part of the work. Even expert processes are susceptible to a preference for interest bargaining instead of evidence.

Edelman's (1988) concept of "condensation symbols" is a useful tool in thinking about curriculum politics. Edelman argues that even relatively small instances become highly symbolic as they seem to embody, or condense, a range of beliefs and values in a particular case. The example below of calculus in the Ontario curriculum provides a good illustration of this idea. It is possible to think of many others. For example, a columnist writes an article pointing out that Canadian students cannot name most of the country's prime ministers, a point which gets translated into a signal of all that some people find wrong with contemporary education, such 
as its supposed focus on learning process without content or its embracing of multiple instead of traditional values. As noted in the earlier part of the chapter, even small incidents can turn into significant political issues if they press the right buttons for enough people.

\section{Results}

It has been at least 20 years since it became evident that there is a large gap between producing a curriculum and the experience of students in the classroom. A substantial body of research (e.g., Cohen, Raudenbush, \& Ball, 2003; Wilson, Peterson, Ball, \& Cohen, 1996) shows how far classroom practice can be from new curricula and how little impact a change in curriculum can have on teaching practice. The more significant the proposed change, the more likely it is to have limited adoption. Working practices of teachers are shaped primarily by day to day realities of their workplace, their habits, and their views about what is practical. Insofar as curriculum changes do not pay attention to these realities they further limit their chances of having an effect.

Research has helped develop understanding of the factors that do shape implementation. Fullan's (1991) work has been particularly important and influential. However, these considerations may still not be well integrated into formal curriculum processes, as it is still common to find accounts of some new program that was carefully developed only to fall far short in the implementation stage. As this chapter has illustrated, issues of implementation and results are often marginal to the entire curriculum process.

\section{A Case Example: \\ Calculus as a Condensation Symbol}

The patterns described in this chapter can be illustrated by an example drawn from my own experience.

For many years the province of Ontario had 5 years of high school while almost all other Canadian provinces, like United States, had 4 years. Although at one time the 5th year had been primarily for a relatively small number of university-bound students, over time Grade 13 became a normal part of the high school system for most students. The elimination of this extra year had been proposed several times, but it was only in the 1990s that the Ontario government finally moved to a 4 year high school system consistent with other Canadian provinces and United States. Over a period of 6 or 7 years, the entire high school program was reshaped, including new curricula in every subject. Toward the end of the process, when many of the key curriculum decisions were being made, the government of the time had a focus on high standards, so for some subjects, including mathematics, most of what had been in the 5 year high school curriculum was compressed into 4 years. The changes in the high school program and curriculum were also being made at the same time as many other controversial changes, so the whole atmosphere in education in the late 1990s was highly conflictual; teachers were quite unhappy with the state of things, which spilled over into their views about curriculum.

The former 5 year mathematics curriculum had provided substantial opportunity for students to take advanced level courses in specialized areas such as calculus. The new curriculum for the 4 year program did not provide the same opportunity. As a result of pressure from some university departments such as engineering and physics and from some employers as well as some passionate and vocal teachers, calculus continued to be included, but it became part of a larger advanced mathematics course in Grade 12. The debate over the role of calculus was loud, public, and often framed as lowering standards in mathematics, a criticism to which the government was highly sensitive.

Shortly after the new high school curriculum was in place, the Ministry of Education began to review the various components as part of a regular curriculum review cycle. In 2003, high school mathematics was reviewed using a new process with wider participation. The review committee was made up of Ministry staff, including mathematics experts, working with various partners including teachers and postsecondary math experts. Ministry curriculum committees do not, however, typically include community or employer representatives.

One of the many issues in front of this committee was a concern about calculus. Enrollment in advanced mathematics courses was dropping steadily because students found them very hard 
due to so many topics in a limited time. At the same time, university mathematics departments were expressing concern in that the time allowed for calculus in the new course was not sufficient and resulted in students being inadequately prepared. The consensus of the university mathematics departments was that they would prefer to do their own teaching of calculus.

Late in 2004, the curriculum review group recommended, based on all its discussions and consultations, the elimination of calculus from the Grade 12 mathematics curriculum and the reorganization of the advanced mathematics courses.

Before finalizing these recommendations for presentation to senior managers and the Minister, the Curriculum Branch sought feedback on their proposals. Very quickly a public uproar began. The primary impetus for the concern came from three sources-high school teachers of calculus, university faculty in engineering and physics, and some well-known leaders of high tech industries. Several prominent people wrote letters to newspapers expressing great concern, while many others also expressed contrary views in public. Examples of these concerns include the following:

Head of UW [University of
Waterloo] Slams Math Plan

Ontario's high school graduates are already slipping in their math abilities - and the government's decision to drop calculus from the high school curriculum puts these students in even more peril says the president of the University of Waterloo.

David Johnson has written Education Minister Gerrard Kennedy, warning of the university's "great concern" if calculus is dropped from math courses next year, as Is planned.

The Record, 2005, December 23

When It Comes to Calculus, An Artificial Tree Is Preferred

... But while university math types are in favour $[$ sic] of taking calculus out of high schools, [a local professor] acknowledged engineering schools aren't.
The engineering schools expect first-year students to come in with a grasp of certain calculus concepts, he said, and they are not set up to make the required teaching adjustments as easily as math departments are.

Perhaps feeling the heat over the dumbing-down charges, a spokeswoman for education minister Gerard Kennedy said this week nothing had been finalized and only certain sections of high school calculus were being removed from the curriculum.

The Standard, 2005, December 23

\section{Scrapping Calculus Course Opposed: It's Crucial for Science... .}

... [The] chair of University of Western Ontario's math department wants the government to offer an optional course with a significant portion of calculus so strong students can be enriched. It "enables them to come to university with a reasonable sense of what it's about," [he] said. His department teaches first-year calculus to a broad range of students from science and social science programs.

$$
\begin{array}{r}
\text { The Observer (Sarnia), 2006, } \\
\text { February } 23
\end{array}
$$

It was clear almost immediately that this was not an argument the government or Ministry could win, even though the proposals made by the review were logical and could well be in the best interests of students' mathematics skills. Although only a very small proportion of the adult population ever studied calculus, and even fewer use it in their daily lives, it became clear that calculus was symbolic of advanced skills and global competitiveness in the Ontario economy. People might not want to learn calculus themselves, but many apparently regard it as essential for their children. At the same time, the status quo ante was untenable in light of dropping enrollments and unsatisfactory outcomes.

The Minister decided to convene a new process to look at the calculus issue. The government's education platform had included a commitment to create a new Curriculum Council made up of parents, students, and employers as well as educators as a way of managing some of the tensions 
in curriculum described earlier in this chapter. Due to pressure of other commitments, this promise had not yet been acted on when the calculus debate erupted early in 2005. The Minister saw the calculus debate as an opportunity to test the ideas behind the Curriculum Council.

He therefore announced a new review group. This process would be more sensitive to the various public views than was the original, expertdominated process. The Ministry put together a small team to review the status of calculus. Unlike Ontario's standard curriculum reviews, which involve large teams and take a year or more, the calculus review team had only five members, was not dominated by people from the school system, had a very specific mandate, and had a short timeline. It was led by a highly respected mathematics professor who was also deeply involved in the applications of mathematics in industry. The group included a senior executive of a high tech company, an educator, a high school student, and a parent, so it was heavily weighted with nonexperts. The group was asked to look at the recommendations of the review team, but also to consult with employers and others so as to assess based on economic realities the appropriate role for calculus. The Ministry was asked to prepare an analysis of the uses of mathematics in the Ontario labor force so that we could have reasonable evidence on real requirements rather than supposition. Because of the need to have decisions in time to shape student course choices for the following year, the group was given a very short timeline for its work.

This process unfolded reasonably well especially given its rather ad hoc nature and short timeline. The team met with a variety of interested parties, looked at the evidence on coursetaking patterns, and wrote a report with a series of recommendations, all of which were accepted by the government. They found a useful compromise that would preserve calculus without reverting to the prior set of course offerings that were clearly not working well. The acceptance of their report also ended the public debate.

At the same time, the process revealed some challenges for further development of this alternative approach. One intention of the task force had been to root the discussion more deeply in evidence on the place of advanced mathematics in the Ontario economy. How many workers used calculus and for what purposes? That would help root school curriculum choices in real information instead of mythology. It turned out to be very difficult to reorient the discussion in this way. From a political point of view, the established interest groups were highly vocal and largely uninterested in such evidence. A good example would be university business schools that may require calculus either for admission or as part of their own program of studies even though it is rarely used by actual managers in business. Industry groups, who might have been able to exert some influence over the debate, were largely uninterested and unwilling to take the time either to provide evidence or to participate in discussions. The working group itself had a hard time keeping its attention on economic evidence as well since it was subject to the same pressures to manage demands from interest groups and since, not surprisingly and especially given its short timeline, it began looking very early on for compromise solutions.

\section{Conclusion}

Although curriculum is a fundamental part of the framework of schooling, curriculum decisions and choices are shaped in large measure by other considerations-ideology, personal values, issues in the public domain, and interests. Curriculum decisions are often part of a much larger public debate that often extends beyond education to larger questions of public goods.

These dynamics tend to be poorly understood by most educators, who tend to believe that education policy choices can and should be made on the basis of educational expertise. When processes are put in place without adequate regard for the real drivers of decisions, the likelihood of poor decisions-that is, decisions that fail to produce the intended resultsincreases. Political processes are driven by interests, and particularly by the most vocal interests. Finding ways to mediate interests through different processes and uses of evidence will remain a challenge, though one worth pursuing.

\section{REFERENCES}

Allington, R. (2002). Big Brother and the national reading curriculum: How ideology trumped evidence. New York: Heineman. 
Arrow, K. (1970). Social choice and individual values (2nd ed.). New Haven, CT: Yale University Press.

Ball, S. (1987). The micro-politics of the school. London: Methuen.

Ball. S. (1990). Politics and policy making in education: Explorations in policy sociology. London: Routledge.

Bascia, N., Cumming, A., Datnow, A., Leithwood, K., \& Livingstone, D. (Eds.). (2005). International handbook of educational policy. Dordrecht, Netherlands: Springer.

Bernhardt, V. (2003). Data analysis for continuous school improvement. Larchmont, NY: Eye on Education.

Black, P., \& William, D. (1998). Inside the black box. Phi Delta Kappan, 80, 39-148.

Boston, J., Martin, J., Pallot, J., \& Walsh, P. (1996). Public management: The New Zealand Model. Auckland, New Zealand: Oxford University Press.

Cohen, D. K., \& Spillane, J. P. (1992). Policy and practice: The relations between governance and instruction. In G. Grant (Ed.), Review of research in education (Vol. 18, pp. 3-49). Washington, DC: American Educational Research Association.

Cohen, D. K., Raudenbush, S. W., \& Ball, D. L. (2003). Resources, instruction, and research. Educational Evaluation and Policy Analysis, $25,119-142$.

Coles, G. (2003). Reading the naked truth: Literacy, legislation and lies. Portsmouth, $\mathrm{NH}$ : Heinemann.

COMPAS. (2001). The educational experience: State of the nation. Q2, Public Opinion on Education. A COMPAS/National Post Poll with Supplementary Questions for Global Television [Electronic version]. Ottawa, Toronto, Canada: Author.

Crowson, R. L., Boyd, W. L., \& Mawhinney, H. B. (1996). The politics of education and the new institutionalism: Reinventing the American school. London: Falmer.

Dror, Y. (1986). Policy-making under adversity. New Brunswick, NJ: Transaction Books.

Edelman, M. (1988). Constructing the political spectacle. Chicago: University of Chicago Press.

Edelman, M. (2001). The politics of misinformation. Cambridge, UK: Cambridge University Press.

Evans, J., \& Penney, D. (1995). The politics of pedagogy: Making a national curriculum in physical education. Journal of Education Policy, $10,27-44$.

Fullan, M. (1991). The new meaning of educational change (2nd ed.). New York: Teachers College Press/OISE Press.

Fullan, M. (2000). The return of large-scale reform. Journal of Educational Change, 1, 5-28.

Hargreaves, A., Lieberman, A., Fullan, M., \& Hopkins, D. (1998). International handbook of educational change. Dordrecht, Netherlands: Kluwer Academic.

Howlett, M., \& Ramesh, M. (2003). Studying public policy (2nd ed.). Toronto, Ontario, Canada: Oxford University Press.

Hoyle, E. (1982). Micropolitics of educational organizations. Educational Management and Administration, 10, 87-98.

Kiesler, S., \& Sproull, L. (1982). Managerial response to changing environments: Perspectives on problem sensing from social cognition. Administrative Science Quarterly, 27, 548-570.

Kingdon, J. (1994). Agendas, alternatives and public policies (2nd ed.). New York: HarperCollins.

Lasswell, H. (1958). Politics: Who gets what, when, how. Cleveland, $\mathrm{OH}$ : Meridian.

Levin, B. (2001). Reforming education: From origins to outcomes. London: RoutledgeFalmer.

Levin, B. (2002). Knowledge and action in education policy and politics. In A. Sweetman \& P. de Broucker (Eds.), Towards evidence-based policy in Canadian education (pp. 1-15). Montreal, Quebec, Canada: McGill-Queen's University Press.

Levin, B. (2004a). Government and the media in education. Journal of Education Policy, 19, 271-284.

Levin, B. (2004b). Students at risk: A review of research. Report to The Learning Partnership. Retrieved October 15, 2006, from http://www .thelearningpartnership.ca/policy_research/ studentsatrisk_by_Ben_Levin.pdf

Levin, B. (2005). Governing education. Toronto, Ontario, Canada: University of Toronto Press.

Levin, B. (in press). Good times ahead: An argument that things might be getting better. In C. Sugrue (Ed.), The future of educational change. London: RoutledgeFalmer.

Levin, B., \& Young, J. (2000). The rhetoric of educational reform. International Journal of Comparative Policy Analysis, 2, 189-209.

Luke, A. (2004). After the marketplace: Educational research, accountability and evidence-based policy. Australian Educational Researcher, 9, 43-73.

Manzer, R. (1994). Public schools and political ideas. Toronto, Ontario, Canada: University of Toronto Press.

Marzano, R. (2003). What works in schools: Translating research into action. Alexandria, VA: Association for Supervision and Curriculum Development.

McLaughlin, M. (1987). Learning from experience: Lessons from policy implementation. Educational Evaluation and Policy Analysis, 9, 171-178.

National Reading Panel. (2000). Report of the National Reading Panel: Reports of the subgroups. Washington, DC: National Institute of Child Health and Human Development Clearinghouse. 
Neuman, R., Just, M., \& Crigler, A. (1992). Common knowledge: News and the construction of political meaning. Chicago: University of Chicago Press.

Plank, D., \& Boyd, W. L. (1994). Antipolitics, education, and institutional choice: The flight from democracy. American Educational Research Journal, 31, 263-281.

Pressley, M. (2005). Balanced elementary literacy instruction in the United States: A personal perspective. In N. Bascia, A. Cumming, A. Datnow, K. Leithwood, \& D. Livingstone (Eds.), International handbook of educational policy (pp. 645-660). Dordrecht, Netherlands: Springer.

Proust, M. (2004). In search of lost time: Swann's way (Vol. 1, C. K. Scott Moncrieff, Trans.). New
York: The Modern Library. (Original work published 1913)

Schoenfeld, A. (2006). What doesn't work: The challenge and failure of the What Works Clearinghouse to conduct meaningful reviews of studies of mathematics curricula. Educational Researcher, 35, 13-21.

Tinder, G. (1991). Political thinking: The perennial questions (5th ed.). New York: HarperCollins.

Wildavsky, A. (1979). Speaking truth to power. Boston: Little, Brown.

Wilson, S., Peterson, P., Ball, D., \& Cohen, D. (1996). Learning by all. Phi Delta Kappan, 77, 468-476.

Young, J., Levin, B., \& Wallin, D. (2007). Understanding Canadian schools (4th ed.). Toronto, Ontario, Canada: Nelson Thomson. 